\title{
Chapter 2 \\ Why Investment Arbitration and Not \\ Domestic Courts? The Origins \\ of the Modern Investment Dispute \\ Resolution System, Criticism, and Future \\ Outlook
}

This Chapter first summarizes the criticism voiced against investment treaty arbitration with specific regard to its relationship with domestic courts (infra at Sect. 2.1). It does not seek to discuss all of the multiple concerns raised against investment arbitration, which have already been addressed in the authors' First CIDS Report ${ }^{1}$ and are further examined in the UNCITRAL Secretariat's papers, ${ }^{2}$ among other materials. ${ }^{3}$ Discussing the criticism of investment arbitration vis-à-vis domestic courts requires providing an overview of the main reasons why States created the investment treaty system in the first place (infra at Sect. 2.2) and examining today's justifications for keeping or putting in place an international system of investment dispute resolution, whether in the form of arbitration or standing adjudicatory bodies (infra at Sect. 2.3). The following sub-sections will in particular ask: What goals were IIAs intended to achieve? In light of those goals, what is the function of international courts and tribunals in the investment law domain, either in their current arbitral configuration or in future constellations such as a MIC? As States are considering questions concerning the institutional design and re-design of the system, it appears important to seek to provide answers to these questions in order to test the continuing validity of the assumptions which underpin the conclusion of investment treaties with international dispute resolution mechanisms.

\footnotetext{
${ }^{1}$ See Gabrielle Kaufmann-Kohler and Michele Potestà (2016), First CIDS Report, paras. 18-23.

${ }^{2}$ See, inter alia, the UNCITRAL Secretariat papers cited supra at Chap. 1, footnote 4 . See also Possible reform of investor-State dispute settlement (ISDS): Third-party funding - Note by the Secretariat, A/CN.9/WG.III/WP.157.

${ }^{3}$ See the "Bibliography of writings relating to ISDS reform" prepared by the CIDS available at https://www.cids.ch/academic-forum. 


\subsection{Criticism Over Investment Treaty Arbitration in Relation to Domestic Courts}

11. In recent years, a number of States, academics, and members of civil society have increasingly questioned the justification for maintaining in place a dispute resolution system which allows foreign investors to bring direct claims against sovereign States before international arbitral tribunals rather than before the courts of the host State.

12. Looking at the big picture, there are essentially two inter-related criticisms against investment treaty arbitration vis-à-vis domestic courts. First, it is argued that there is no need to put or maintain in place an international system for the resolution of investment disputes because investors in any event "retain rights under domestic systems" and those systems "are often assumed, but not established, to be inadequate". 4 In other words, the current IIA investment arbitration regime does not account for situations in which domestic courts $d o$ offer adequate access to justice to a foreign investor. ${ }^{5}$ In a similar vein, critics contend that the IIA framework allows investors to bring claims against sovereigns without having to exhaust local remedies in the host State, regardless of whether those remedies are capable of delivering justice. $^{6}$ In fact, IIAs generally remove the duty to exhaust local remedies even for countries that have mature and advanced legal systems. ${ }^{7}$

13. Secondly, critics underscore that the procedural right to resort to arbitration against the host State under an IIA is not available to domestic investors (and foreign investors of nationalities not covered by IIAs). If domestic remedies are assumed to be unreliable, why allow only (certain) foreign investors to benefit from an international adjudicative process? In the eyes of those making this criticism, such differential treatment is seen as unfair and illustrative of "the privileges accorded by less developed countries to multilateral corporations at the expense of local investors who are competitively disadvantaged". 8

14. A number of States, including capital-exporters and traditional supporters of the investment treaty system, have recently invoked principles of primacy of domestic courts over international tribunals and of non-discrimination between local and foreign investors in justification of anti-investment arbitration policies. The idea that foreign investors should enjoy no greater rights than domestic investors, including procedural rights, ${ }^{9}$ has been put forward by a range of actors, such as the

\footnotetext{
${ }^{4}$ Lise Johnson, Lisa Sachs, Brooke Güven, and Jesse Coleman (2018), Clearing the Path: Withdrawal of Consent and Termination as Next Steps for Reforming International Investment Law, Columbia Center on Sustainable Development Policy Paper, April 2018, p. 10.

${ }^{5}$ Van Harten (2010), p. 34.

${ }^{6}$ Van Harten (2010), p. 35.

${ }^{7}$ Van Harten (2010), p. 35.

${ }^{8}$ Trackman (2012), p. 994 (discussing the criticism).

${ }^{9}$ Whether IIAs grant greater substantive rights than those provided under the relevant domestic systems of States entering into those IIAs is controversial and it likely depends on the laws of the relevant State. With regard to U.S. IIAs, Parvanov and Kantor conclude that U.S. IIAs generally do
} 
Australian Government, the European Parliament, and the U.S. Administration under President Trump, among others. ${ }^{10}$ In 2011, for instance, the Australian Government headed by Prime Minister Gillard openly indicated that it would no longer agree to investment arbitration in its treaties based, inter alia, on reasons of equal treatment between foreign and domestic investors. ${ }^{11}$ In its 2015 recommendations to the European Commission on the negotiations of the Transatlantic Trade and Investment Partnership (TTIP), the European Parliament called on the Commission "to ensure that foreign investors are treated in a non-discriminatory fashion and have a fair opportunity to seek and achieve redress of grievances, while benefiting from no greater rights than domestic investors, and to oppose the inclusion of ISDS

not confer greater substantive rights on foreign investors than the protection afforded to domestic investors under comparable U.S. domestic law (Parvanov and Kantor 2012, pp. 741-836); Johnson and Volkov come to an opposite conclusion and argue that fair and equitable treatment provisions in BITs are more favorable to foreign investors than U.S. law (Johnson and Volkov 2013, pp. 361-415). With respect to EU law, Kleinheisterkamp also finds that investment treaties provide more generous rights than EU law (Kleinheisterkamp 2012, pp. 85-109). Bonnitcha, Poulsen, and Waibel note that these debates are particularly controversial because both the U.S. Congress and the European Parliament have issued directives to their countries' treaty negotiators stating that investment treaties should not provide greater substantive rights than are available under their respective national laws (see infra in the text, para. 14). However, they are of the view that "because relatively little research has been done comparing the substantive rights in investment treaties with those available under domestic law, it is unclear whether the directives are being followed in practice." See Bonnitcha et al. (2017), p. 153. With regard to procedural rights, it is undisputed that the investor-State arbitration mechanism is not offered as a remedy under domestic law.

${ }^{10}$ See also South African Department of Trade and Industry, Government Position Paper on Bilateral Investment Treaty Policy Framework Review (Pretoria, June 2009), p. 45 (noting that "[t]here is no compelling reason why review of an investor's claims against a state cannot be undertaken by the institutions of the state in question - provided these are independent of the public authority that is in dispute and they discharge their duties in accordance with basic principles of good governance, including an independent judiciary. Unfortunately, there is little indication in the texts of BITs that negotiators have acted with prudence to promote better domestic dispute settlement in the host state").

${ }^{11}$ See Australian Government (Department of Foreign Affairs and Trade), Gillard Government Trade Policy Statement: Trading our way to more jobs and prosperity (April 2011), p. 14 (stating that "[t]he Gillard Government supports the principle of national treatment - that foreign and domestic businesses are treated equally under the law. However, the Government does not support provisions that would confer greater legal rights on foreign businesses than those available to domestic businesses. [...] In the past, Australian Governments have sought the inclusion of investor-state dispute resolution procedures in trade agreements with developing countries at the behest of Australian businesses. The Gillard Government will discontinue this practice. If Australian businesses are concerned about sovereign risk in Australian trading partner countries, they will need to make their own assessments about whether they want to commit to investing in those countries"). Following changes in government, the policy appears to have changed, as now Australia considers inclusion of investor-State arbitration clauses "on a case-by-case basis". See Australian Government (Department of Foreign Affairs and Trade), "Investor-State-Dispute-Settlement (ISDS)", available at https://dfat.gov.au/trade/investment/Pages/investor-state-dispute-set tlement.aspx. See also Amokura Kawharu and Luke Nottage (2018), Renouncing Investor-State Dispute Settlement in Australia, then New Zealand: Déjà vu, The University of Sydney Law School Legal Studies Research Paper Series No. 18/03 (February 2018), p. 5. 
in the TTIP, as other options to enforce investment protection are available, such as domestic remedies". ${ }^{12}$ In the context of the recent NAFTA re-negotiations, the U.S. Trade Representative explained to Congress that the U.S. Government was "skeptical about ISDS" inter alia because investor-State arbitration grants "a foreign national [. . . more rights than Americans have in the American court system", ${ }^{13}$ and suggested that investors should resort to State-to-State dispute settlement or negotiate arbitration provisions in their contracts as more appropriate alternatives. ${ }^{14}$

15. Although not always expressly articulated in these terms, these positions appear to question the very premise upon which the system was created. Indeed, it is often argued that the reasons why an international forum for the settlement of investment disputes was established included the need to provide (i) a neutral forum as alternative to domestic courts that were perceived as inadequate, and (ii) a substitute to traditional State-to-State "politicized" mechanisms. These reasons are analyzed in the next chapter on the origins of the investor-State arbitration regime, together with

\footnotetext{
${ }^{12}$ European Parliament (2015) Opinion of the Committee on Legal Affairs for the Committee on International Trade on recommendations to the European Commission on the negotiations for the Transatlantic Trade and Investment Partnership (2014/2228INI), 4 May 2015, Rapporteur Dietmar Köster, p. 4. See also Opinion of the European Committee of the Regions (2015), 110th Plenary Session, 11-13 February 2015, (2015/C 140/02), 28 April 2015, paras. 33-35.

${ }^{13}$ See U.S. Trade Representative Robert Lighthizer at hearing before the U.S. Congress Ways and Means Committee, 21 March 2018 (transcript available on the International Economic Law and Policy Blog at https://worldtradelaw.typepad.com/ielpblog/2018/03/brady-lighthizer-isdsexchange.html and video available at https://www.c-span.org/video/?c4719932/brady-lighthizerisds-discussion (where U.S. Trade Representative Robert Lighthizer noted that "[w]e are skeptical about ISDS for a variety of reasons [...]. Number one, on the U.S. side there are questions of sovereignty. Why should a foreign national be able to come in and not only have the rights of Americans in the American court system but have more rights than Americans have in the American court system? It strikes me as something that at least we ought to be skeptical of and analyze. So a U.S. person goes into a court system, goes through the system and they're stuck with what they get. If a foreign national can do that and then at the end of the day say 'I want three guys in London to say we're going to overrule the entire US system.' [...] So this is troubling in that respect"). The renegotiations of the NAFTA resulted in the conclusion of the so-called USMCA which eliminated future investor-State arbitration as between the U.S. and Canada and curtailed its scope as between the U.S. and Mexico. See Galbraith (2019), pp. 150-159.

${ }^{14}$ See U.S. Trade Representative Robert Lighthizer at hearing before the U.S. Congress Ways and Means Committee, 21 March 2018, supra Chap. 2, footnote 13 (stating that "[o]ur view was that rather than have this mandatory ISDS provision, which we think is a problem in terms of our sovereignty in the United States, encourages outsourcing and losing jobs in the United States, and by the way lowering standards in a variety of places, that we should be very careful before we put something like that into place. So you say 'What are the risks, what are the alternatives for these companies?' The first alternative I'd say is state-to-state dispute settlement, the second alternative is if you go to any one of these companies and ask them 'Why do you need this; why don't you put in place an arbitration provision in your contract?' They'll all say 'Well we could do that,' and indeed they did do it-did it before we had ISDS. In a country like Mexico they subscribe to all the conventions and they have to enforce those. If they put [an] arbitration provision in their contract, these things are then resolved in a similar manner, but without the United States ceding sovereignty in order to encourage people to outsource jobs. It's just not a good trade in my opinion”).
} 
others that were invoked to justify the creation of the investment treaty system (infra at Sect. 2.2).

\subsection{The Origins of Investor-State Arbitration}

This chapter starts by describing the pillars on which the existing investment treaty arbitration framework rests, namely the ICSID Convention and the complex network of IIAs, the majority of which include investor-State arbitration clauses (infra at Sect. 2.2.1). It then provides a brief overview of the main reasons that are often put forward for the creation of the investment treaty system (infra at Sect. 2.2.2), namely the need to attract foreign investment (infra at Sect. 2.2.2.1); the desire to "depoliticize" investment disputes (infra at Sect. 2.2.2.2); and the desire to establish a neutral forum on the international plane as an alternative to domestic courts perceived to be inadequate (infra at Sect. 2.2.2.3). Bearing the ongoing reform discussions in mind, it then provides an evaluation of whether today's world still needs an international system for the resolution of investment disputes (in the form of arbitration or standing adjudicatory bodies) (infra at Sect. 2.3).

\subsubsection{The Pillars of the Investment Treaty Arbitration Framework: The ICSID Convention and the IIAs}

The existing investor-State arbitration framework emerged in its modern form in the 1960s, with the conclusion of the ICSID Convention and the first BITs. ${ }^{15}$ The investment treaty network has grown since then to comprise more than 3000 IIAs binding a multitude of States worldwide. Switzerland is amongst the 154 Contracting States to the ICSID Convention and has concluded over 110 BITs with its trade partners. ${ }^{16}$ Along with Germany, Switzerland was one of the first countries to

\footnotetext{
${ }^{15}$ For historical accounts see Newcombe and Paradell (2009), pp. 44-46, para. 1.31; Miles (2013), pp. 86-87. As Newcombe and Paradell explain, "uniqueness of the current IIA network is a product of an historical evolution going as far back as the Middle Ages. Prior to the twentieth century, international standards of foreign investment and investor protection developed primarily through the related processes of diplomatic protection and claims commissions. In the late nineteenth and early twentieth centuries, as the world economy became increasingly internationalized, the limits of the diplomatic protection model became apparent, particularly as controversies arose between capital exporting and importing states regarding the customary international law minimum standard of treatment to be accorded to foreign investors and investments. In the aftermath of the Second World War (WWII), the process of international economic integration was rekindled, leading to the emergence of the contemporary investment treaty framework." (citations omitted) pp. 2-3.

${ }^{16}$ See SECO, "Overview of BITs - List of BITs concluded by Switzerland - May 21st 2019", available at https://www.seco.admin.ch/seco/en/home/Aussenwirtschaftspolitik_Wirtschaftliche_ Zusammenarbeit/Wirtschaftsbeziehungen/Internationale_Investitionen/Vertragspolitik_der_
} 
develop a BIT program and is today one of the economies with the widest IIA network worldwide. ${ }^{17}$

18. The ICSID Convention was concluded in 1965 under the aegis of the World Bank and provides for a mechanism for the settlement of investment disputes available to foreign investors and host States in the form of both conciliation and arbitration. More specifically in relation to arbitration, ${ }^{18}$ the ICSID Convention allows a Contracting Party and a national of another Contracting Party (thus, to the exclusion of domestic investors) ${ }^{19}$ to settle their disputes arising out of an investment through arbitration, provided the parties have separately consented to it. ${ }^{20}$ The Convention also provides for an effective regime for the enforcement of arbitral awards rendered under the Convention, whereby Contracting Parties undertake to enforce the pecuniary obligations arising out of the award in their territory as if it were a final judgment of their courts. $^{21}$

19. ICSID has administered more than 720 arbitrations to date, most of which in the last two decades. ${ }^{22}$ In the majority of cases, the basis for the jurisdiction of the Centre was an IIA incorporating an investor-State arbitration clause. Indeed, from the end of the $1960 \mathrm{~s}^{23}$ BITs started to include a standing offer from a Contracting Party to submit disputes with the investors of the other Contracting Party to international arbitration, whether ICSID or other arbitral fora, such as UNCITRAL, Stockholm Chamber of Commerce (SCC), or International Chamber of Commerce (ICC). According to UNCTAD, $90 \%$ of the existing IIAs contain advance consent (i.e. by

Schweiz/overview-of-bits.html, listing the BITs concluded by Switzerland. See also UNCTAD, International Investment Agreements Navigator, "Switzerland", available at https:// investmentpolicy.unctad.org/international-investment-agreements/countries/203/switzerland.

${ }^{17}$ See UNCTAD Investment Policy Hub, International Investment Agreements Navigator, "IIAs by Economy", available at https://investmentpolicy.unctad.org/international-investment-agreements/ by-economy.

${ }^{18}$ In practice, the conciliation part of the ICSID Convention has had significantly less importance than the arbitration part.

${ }^{19}$ Subject to the rule in Article 25, para. 2(b), second sentence on local companies subject to foreign control.

${ }^{20}$ The Convention is subject to a "dual-consent" requirement, in the sense that "no Contracting State shall by the mere fact of its ratification, acceptance or approval of this Convention and without its consent be deemed to be under any obligation to submit any particular dispute to conciliation or arbitration". See ICSID Convention, Preamble.

${ }^{21}$ See ICSID Convention, Article 54, para. 1.

${ }^{22}$ See ICSID, The ICSID Caseload - Statistics, Issue 2019-2, p. 7 available at https://icsid. worldbank.org/en/Documents/ICSID_Web_Stats_2019-2_(English).pdf.

${ }^{23}$ The first BIT to contain an unconditional offer of consent to submit disputes between a Contracting Party and an investor of the other Contracting Party to arbitration is considered to be the Italy-Chad BIT of 1969. See Italy-Chad BIT (1969), Article 7, referring to arbitration under the jurisdiction of the ICSID, pursuant to the Washington Convention of 18 March 1965 (the ICSID Convention). See Newcombe and Paradell (2009), p. 45, para. 1.31. 
way of a standing offer) to investment arbitration. ${ }^{24}$ In 1990, an ICSID arbitral tribunal recognized for the first time the possibility for an investor to sue a host State on the basis of the offer of consent contained in an IIA, ${ }^{25}$ paving the way for the initiation of hundreds of investment treaty claims in the following decades. ${ }^{26}$

\subsubsection{The Reasons for Putting the System in Place}

What were the reasons that prompted States to set up the international treaty framework for the protection of foreign investments, including the grant of direct remedies against host States? Three main reasons are usually advanced for the conclusion of IIAs and, more specifically, for the inclusion of investor-State arbitration therein. First, IIAs, including the grant of direct means of enforcement on the international plane, are said to be aimed at attracting foreign direct investment to host States (infra at Sect. 2.2.2.1). Second, investor-State arbitration is said to pursue the objective of "de-politicizing" disputes (infra at Sect. 2.2.2.2). Third, and of direct relevance to the subject matter of this study, IIAs provide international remedies directly to foreign investors with a view to affording foreign investors an alternative to domestic courts which are perceived to be inadequate for the resolution of investment disputes (infra at Sect. 2.2.2.3).

\subsubsection{Do Investment Treaties Increase Foreign Investment Flows?}

If one looks at the preamble to the ICSID Convention, the very first consideration recorded by States for the conclusion of that Convention is "the need for international cooperation for economic development, and the role of private international investment therein". ${ }^{27}$ The Report of the Executive Directors of the International Bank for Reconstruction and Development, or World Bank, which accompanies the

\footnotetext{
${ }^{24}$ According to UNCTAD, 95\% of IIAs provide "advance consent to international arbitration". See UNCTAD 2018 World Investment Report, Investment and New Industrial Policies, p. 106 available at https://unctad.org/en/PublicationsLibrary/wir2018_en.pdf.

${ }^{25}$ Asian Agricultural Products Ltd. v. Republic of Sri Lanka, Final Award, ICSID Case No. ARB/87/3, Final Award, 27 June 1990, paras. 18-24. See also Pauwelyn (2014), p. 397. A few years before, on 27 November 1985, an ICSID tribunal in its Decision on Preliminary Objections to Jurisdiction had recognized the same possibility under an offer of consent in a domestic law on foreign investment (see Southern Pacific Properties (Middle East) Limited v. Arab Republic of Egypt, ICSID Case No. ARB/84/3, Award on the Merits, 20 May 1992, paras. 3, 15).

${ }^{26}$ According to UNCTAD, as of 1 January 2019, "the total number of known ISDS cases pursuant to [IIAs] had reached 942" in the various arbitral fora (see UNCTAD, Fact Sheet on Investor-State Dispute Settlement Cases in 2018, IIA Issues Note on International Investment Agreements No 2, May 2019, p. 1).

${ }^{27}$ See ICSID Convention, Preamble.
} 
Convention explains the link between the orderly settlement of investment disputes and the stimulation of private international investments and economic development in the following terms ${ }^{28}$ :

9. In submitting the attached Convention to governments, the Executive Directors are prompted by the desire to strengthen the partnership between countries in the cause of economic development. The creation of an institution designed to facilitate the settlement of disputes between States and foreign investors can be a major step toward promoting an atmosphere of mutual confidence and thus stimulating a larger flow of private international capital into those countries which wish to attract it. [...]

The Executive Directors believe that private capital will continue to flow to countries offering a favorable climate for attractive and sound investments, even if such countries did not become parties to the Convention or, having joined, did not make use of the facilities of the Centre. On the other hand, adherence to the Convention by a country would provide additional inducement and stimulate a larger flow of private international investment into its territories, which is the primary purpose of the Convention. ${ }^{29}$

22. Preambles of IIAs, and of BITs in particular, similarly stress the Contracting States' desire to create favorable conditions for greater investments and often declare that the encouragement and reciprocal protection of investments through an international treaty will be "conducive to the stimulation" of foreign direct investment. ${ }^{30}$ Indeed, these objectives are reflected in the headings of many of these treaties, which were traditionally named agreements "on encouragement [or promotion] and reciprocal protection of investments".

23. In recent decades, the question of the impact of IIAs on investment flows has been subject to closer scrutiny. Numerous studies have been conducted with a view to assessing the actual effect on foreign direct investments of (i) IIAs generally and (ii) dispute settlement provisions in IIAs more specifically. Those studies have come to diverging conclusions. ${ }^{31}$

\footnotetext{
${ }^{28}$ See Schreuer et al. (2009), p. 4, citing para. 9 of the Report of the Executive Directors on the Convention on the Settlement of Investment Disputes Between States and Nationals of Other States, Section III, 18 March 1965, para. 9.

${ }^{29}$ Report of the Executive Directors on the Convention on the Settlement of Investment Disputes Between States and Nationals of Other States, Section III, 18 March 1965, paras. 9, 12 (emphasis added). For the discussions during the negotiations of the Convention on whether the proposed instrument would increase foreign investment flows or at least improve the "investment climate", see the comprehensive analysis in St John (2018), pp. 154-161.

${ }^{30}$ See, e.g. U.S. Model BIT (2012), Preamble (whereby the Contracting Parties " $[r]$ ecogniz[e] that agreement on the treatment to be accorded such investment will stimulate the flow of private capital and the economic development of the Parties"); Turkey Model BIT (2009), Preamble ("Recognizing that agreement upon the treatment to be accorded such investment will stimulate the flow of capital and technology and the economic development of the Contracting Parties"); UK Model BIT (2008), Preamble ("Recogni[z]ng that the encouragement and reciprocal protection under international agreement of such investments will be conducive to the stimulation of individual business initiative and will increase prosperity in both States").

${ }^{31}$ See for example Neumayer and Spess (2005), pp. 1582-1583, who find strong evidence that developing countries that sign bilateral investment treaties enjoy significant increases in FDI, as compared to Jennifer Tobin and Susan Rose-Ackerman (2005) (Jennifer Tobin and Susan Rose-
} 
With regard to IIAs in general, according to a 2014 report of the United Nations Conference on Trade and Development (UNCTAD), the majority of the studies reviewed concluded that there was a positive causal relationship between investment treaties and foreign direct investment. ${ }^{32}$ A 2017 review by Bonnitcha, Poulsen, and Waibel of the existing quantitative studies on the effect of investment treaties on FDI concludes that "[a] majority find that investment treaties have a positive and statistically significant impact on inward FDI in at least some circumstances", whereas "a sizeable minority of studies find that there is no statistically significant effect of BIT adoption on FDI flows". 33

The methodological and measurement challenges associated with these empirical studies make it difficult to draw firm conclusions from the existing literature. ${ }^{34}$ As remarked in the UNCTAD report, "an empirical correlation [between the presence of IIAs and FDI] does not necessarily imply causation", and "[t]he causal relationship between IIAs and FDI might theoretically run in both directions". 35 Furthermore, some studies observe that the correlation between BITs and the growth in FDI varies according to the States and the BIT models surveyed and hence conclude that any such positive economic result is not necessarily attributable to BITs. ${ }^{36}$ Market

Ackerman (2005), Foreign Direct Investment and the Business Environment in Developing Countries: The Impact of Bilateral Investment Treaties, Yale Law \& Economics Research Paper No. 293, 2 May 2005) who find a very weak relationship between BITs and FDI, and Mary Hallward-Driemeier (2003) (Mary Hallward-Driemeier (2003), Do Bilateral Investment Treaties Attract FDI? Only a bit. . . and they could bite, World Bank, Policy Research Paper WPS 3121) who finds no effect of BITs on FDI when looking at bilateral FDI flows from OECD countries to developing countries.

${ }^{32}$ UNCTAD (2014), p. 5.

${ }^{33}$ Bonnitcha et al. (2017), p. 159; see also, pp. 179-180, for the list of surveyed studies.

${ }^{34}$ See in particular Bonnitcha et al. (2017), pp. 155-180. See also Chaisse and Bellak (2015), pp. 79-115; Chaisse and Bellak (2011), pp. 3-10.

${ }^{35}$ UNCTAD (2014), p. 5. In a similar vein, a former U.S. BIT negotiator, Kenneth Vandevelde, suggests that capital-exporting States may prioritize BIT negotiations with trade partners that already were hosts to large amounts of their investments, "so that BITs may be caused by investment flows, rather than the other way around". See Vandevelde (1998), pp. 524-525. See also Swenson (2005), pp. 145-149.

${ }^{36}$ See Jennifer Tobin and Susan Rose-Ackerman (2005), Foreign Direct Investment and the Business Environment in Developing Countries: The Impact of Bilateral Investment Treaties, Yale Law \& Economics Research Paper No. 293, 2 May 2005, p. 23. 
factors and other host country factors, ${ }^{37}$ including institutional quality ${ }^{38}$ and the level of political risk,$^{39}$ may also be determinative for FDI inflows. Other variables, including the specific content of IIAs, e.g. the incorporation of certain substantive provisions, may also determine the effectiveness of BITs in attracting FDI. ${ }^{40}$

26. Surveys carried out with investors and other economic actors aimed at testing their awareness of the investment treaty system and in particular at understanding whether the presence of an IIA affects their investment decisions have also led to mixed results. ${ }^{41}$

27. In addition, a number of studies have specifically focused on the possible effect of investment treaty arbitration provisions on FDI flows. ${ }^{42}$ Certain studies have found that there is weak evidence of a relationship between the international dispute settlement provisions included in IIAs and FDI ${ }^{43}$ and that investment treaties that provide advance consent to arbitration are no more effective in attracting FDI than those that do not. ${ }^{44}$ In a 2010 report, Australia's Productivity Commission referred to

\footnotetext{
${ }^{37}$ Tobin and Rose-Ackerman (2006), pp. 18-21, discussing, inter alia, the impact of entering into a BIT with an OECD country; Allee and Peinhardt (2011), pp. 429-430, discussing the role of facing BIT claims on FDI flows; Tortian (2012), pp. 21-22, discussing, inter alia, the market and growth variables for OECD countries' investors. See also Jennifer Tobin and Susan Rose-Ackerman (2005), Foreign Direct Investment and the Business Environment in Developing Countries: The Impact of Bilateral Investment Treaties, Yale Law and Economics Research Paper No. 293, 2 May 2005, pp. 1-52, 15, 21; Jason W. Yackee (2006), Sacrificing Sovereignty: Bilateral Investment Treaties, International Arbitration, and the Quest for Capital, USC CLEO Research Paper No. C06-15, pp. 2-92, 19-20.

${ }^{38}$ Till Siegmann (2007), The Impact of Bilateral Investment Treaties and Double Taxation Treaties on Foreign Direct Investments, University of St. Gallen Law School Law and Economics Research Paper Series, Working Paper No. 2008-22 (November 2007), discussing, inter alia, institutional quality.

${ }^{39}$ Jason W. Yackee (2007), Do BITs Really Work? Revisiting the Empirical Link Between Investment Treaties and Foreign Direct Investment, Legal Studies Research Paper Series (University of Wisconsin Law School), Paper No. 1054 (October 2007), pp. 7-8, discussing, inter alia, political risk.

${ }^{40}$ See Berger et al. (2013), p. 268.

${ }^{41}$ See in particular Bonnitcha et al. (2017), pp. 164-166, with references to studies, concluding that "[t]he results are mixed. Taken together, the literature suggests that investment treaties do have some impact on some investment decisions in some circumstances, but that they are unlikely to have a large effect on the majority of foreign investment decisions".

${ }^{42}$ See, e.g. Frenkel and Walter (2019), pp. 1316-1342.

${ }^{43}$ See Berger et al. (2013), p. 268; See also Berger et al. (2011), pp. 270-272.

${ }^{44}$ See, e.g., Yackee (2008), pp. 808-809 and 827-828; Berger et al. (2011), p. 272.
} 
some of these studies ${ }^{45}$ as one of the bases for its recommendation that Australia no longer include investment arbitration in its future IIAs. ${ }^{46}$

By contrast, a different line of research identifies a positive impact of IIAs on FDI inflows, particularly when treaties include investment arbitration mechanisms. ${ }^{47}$ Some scholars suggest that, among the various IIA provisions, investor-State arbitration clauses matter the most for foreign direct investment flows. ${ }^{48}$ A 2016 research report conducted by the Asian Development Bank concluded that "BITs specifically granting access to [investor-State arbitration] have large, positive, and statistically significant effects on FDI". ${ }^{49}$ A 2017 study covering a large number of countries and surveying different types of dispute settlement clauses similarly concludes that "stronger international dispute settlement provisions in BITs are indeed associated with more FDI activity". 50

In conclusion, the empirical literature, based both on econometric and survey data, is not entirely conclusive on the extent to which IIAs in general and investorState arbitration provisions in particular result in increased FDI.

\subsubsection{De-Politicizing Disputes}

"De-politicization" is often mentioned as one of the reasons for the establishment of the investment arbitration regime and celebrated as one of its central achievements. ${ }^{51}$

\footnotetext{
${ }^{45}$ Australian Government Productivity Commission (2010), Bilateral and Regional Trade Agreements, Research Report, pp. xxxvi, and 269-271 available at: https://www.pc.gov.au/inquiries/ completed/trade-agreements/report/trade-agreements-report.pdf.

${ }^{46}$ See Shiro Armstrong and Luke Nottage (2016), The Impact of Investment Treaties and ISDS Provisions on Foreign Direct Investment: A Baseline Econometric Analysis, Sydney Law School Legal Studies Research Paper No. 16/74 (August 2016), p. 2.

${ }^{47}$ See Kerner (2009), p. 95.

${ }^{48}$ See, e.g., Angus Armstrong and Julian Winkler (2017), Foreign Investment and Shared Sovereignty, National Institute of Economic and Social Research Discussion Paper No. 475 (July 2017). See also Asian Development Bank (2016), ASEAN Economic Integration Report 2016, p. 163.

${ }^{49}$ Asian Development Bank, ASEAN Economic Integration Report 2016, p. 163 (with reference to Tables 6.28 and 6.29).

${ }^{50}$ Frenkel and Walter (2019), p. 1335. See also Shiro Armstrong and Luke Nottage (2016), The Impact of Investment Treaties and ISDS Provisions on Foreign Direct Investment: A Baseline Econometric Analysis, Sydney Law School Legal Studies Research Paper No. 16/74, August 2016, p. 24, finding "evidence that BITs do have a significant and positive impact on FDI flows from OECD countries to their partner host countries"; Rodolphe Desbordes (2017), A Granular Approach to the Effects of Bilateral Investment Treaties and Regional Trade Investment Agreements on Foreign Direct Investment, ABD Working Paper, arguing that BITs specifically granting access to an investor-State dispute mechanism and regional trade investment agreements specifically protecting foreign investors from discrimination have a large, positive, and statistically significant effect on FDI.

${ }^{51}$ As noted by Paparinskis, "[ $\left.\mathrm{t}\right]$ he contemporary State practice, case law and legal writings consider it almost axiomatic that depoliticisation is the purpose of investment protection regime" (see Paparinskis 2010, pp. 271-272). For instance, Michael Reisman argues that the "central
} 
When discussing de-politicization in this context, investor-State arbitration is contrasted with diplomatic protection which, in the pre-investment treaty era, was a common means for investors to secure protection of their foreign investments and obtain reparation for the wrongful act inflicted by host States. "De-politicization" more specifically is understood to refer to the removal of investment disputes from the realm of diplomatic protection in favor of a judicial forum subject to legal rules and a pre-formulated dispute settlement process. ${ }^{53}$

31. Although the views on de-politicization as a desirable feature of investor-State arbitration are not unanimously shared, ${ }^{54}$ and opinions diverge as to whether the rise of investor-State arbitration has actually de-politicized disputes, ${ }^{55}$ it can hardly be doubted that the shift from diplomatic protection to investment arbitration has entailed important consequences for investors, host States, and home States.

32. From the viewpoint of investors, access to an international judicial mechanism removes two major shortcomings associated with diplomatic protection. First, under the traditional conception, the right to exercise diplomatic protection belongs to the home State of the injured national, ${ }^{56}$ and the State enjoys full discretion to pursue the claim or not. ${ }^{57}$ The home State can decide not to exercise diplomatic protection for reasons unrelated to the merits of the claim, for instance, if making a claim would

achievement" of the investment treaty regime is the insulation of investor-State claims from "the caprice of sovereign-to-sovereign politics". See Republic of Ecuador v. United States of America, Expert Opinion with Respect to Jurisdiction in the Interstate Arbitration Initiated by Ecuador Against the United States, W. Michael Reisman, 24 April 2012, PCA Case No. 2012-5, para. 37. Similarly, Andreas Lowenfeld in his Separate Opinion in CPI v. Mexico posits that " $[\mathrm{t}] \mathrm{he}$ essence of [investment treaties] is that controversies between foreign investors and host states are insulated from political and diplomatic relations between states". See Corn Products International, Inc. v. United Mexican States, ICSID Case No. ARB (AF)/04/1, Separate Opinion of Andreas F. Lowenfeld, 18 August 2009, para. 1. See also generally, Shihata (1986), pp. 1-32.

${ }^{52}$ In the words of the ILC, diplomatic protection consists in the "invocation by a State, through diplomatic action or other means of peaceful settlement, of the responsibility of another State for an injury caused by an internationally wrongful act of that State to a natural or legal person that is a national of the former State with a view to the implementation of such responsibility". See Article 1 of the International Law Commission (2006), Draft Articles on Diplomatic Protection, Official Records of the General Assembly, Sixty-first Session, Supplement No. 10, UN Doc. A/61/10.

${ }^{53}$ See, e.g., Kriebaum (2018), p. 15.

${ }^{54}$ For a conceptual critique of the de-politicization argument, see Paparinskis (2010), pp. 271-282.

${ }^{55}$ Compare Noel Maurer (2013), with Gertz et al. (2018), pp. 238-252 (who posit that the U.S. Government routinely intervenes in investment disputes where such intervention aligns with the U.S.' strategic interests). See also Joachim Pohl (2018), Societal benefits and costs of International Investment Agreements: A critical review of aspects and available empirical evidence, OECD Working Papers on International Investment, No. 2018/1, pp. 48-55.

${ }^{56}$ The Mavrommatis Palestine Concessions (1924) PCIJ Ser. A, No. 2, para. 21 where the Court held that "[b]y taking up the case of one of its subjects and by resorting to diplomatic action or international judicial proceedings on his behalf, a State is in reality asserting its own rights - its right to ensure, in the person of its subjects, respect for the rules of international law". See also Orrego Vicuña (2004), pp. 31-32.

${ }^{57}$ Barcelona Traction, Light and Power Company Limited (Belgium v. Spain), Judgment, I.C.J. Reports 1970, para. 79. 
compromise its "diplomatic, military or geo-political objectives". ${ }^{58}$ It also retains full control over the process (including the possibility to settle the claim) and any remedy awarded as a result of the exercise. Second, as a rule, "[a] State may not present an international claim in respect of an injury to a national or other person [...] before the injured person has [...] exhausted all local remedies". 59 The situation is markedly different in investor-State arbitration, where the aggrieved investor enjoys direct access to an international judicial forum, without depending on the intervention of its home State, has control of the process, directly benefits from any remedy awarded, and normally need not exhaust all local remedies.

The shift from diplomatic protection to investor-State arbitration is also said to benefit both the host State and the home State. Host States potentially avoid the risk of confrontations with the investor's home State. ${ }^{60}$ For their part, home States may distance themselves from the investment dispute as the investor is able to litigate its claim directly without engaging the political organs of the two governments. ${ }^{61}$

While the objective of depoliticizing disputes is not easy to trace in the development of the IIA programs of many States, 62 "de-politicization was clearly on the minds of the architects of ICSID". 63 Aron Broches, the then General Counsel of the World Bank and principal architect of the Convention, repeatedly stressed that one of the primary goals of the Convention was "to remove investment disputes from the intergovernmental political sphere" 64 and presented the Convention as offering "a means of settling directly, on the legal plane, investment disputes between the State and foreign investor, [which] would insulate such disputes from the realm of politics and diplomacy". ${ }^{65}$ The Convention further eliminated the requirement for the exhaustion of local remedies, unless otherwise agreed (Article 26) and significantly

\footnotetext{
${ }^{58}$ Newcombe and Paradell (2009), p. 6.

${ }^{59}$ Article 14, para. 1 of the International Law Commission (2006), Draft Articles on Diplomatic Protection, Official Records of the General Assembly, Sixty-first Session, Supplement No. 10, UN Doc A/61/10.

${ }^{60}$ See Schreuer et al. (2009), p. 416 (noting that "[d]iplomatic protection in investment disputes by capital exporting countries against developing countries has been a frequent source of irritation for the latter").

${ }^{61}$ Price (2011), p. 112; see also Price (2000), p. 427.

${ }^{62}$ In his extensive writings on the U.S. BIT program, former BIT negotiator Kenneth Vandevelde identifies de-politicization as one among several policy objectives of the architects of the U.S. investment treaty program (see, e.g. Vandevelde (2009), pp. 29-30; Vandevelde (1988), pp. 163-164). In respect of European States, it is argued that "[t]he objective of de-politicizing investment disputes played next to no role in the initiation and development of European BIT programmes". See Bonnitcha et al. (2017), p. 197.

${ }^{63}$ Bonnitcha et al. (2017), p. 198.

${ }^{64}$ See Broches (1995), p. 163, quoted in St John (2018), p. 103.

${ }^{65}$ ICSID (1968), pp. 242 and 303. Broches' successor Ibrahim Shihata also emphasized the depoliticization aspect of the Convention. See Shihata (1986), p. 5. On depoliticization during the negotiation of the Convention, see St John, who in her extensive review of the ICSID negotiating history argues that certain government officials participating in the negotiations "understood that claims about improving the investment climate or 'depoliticizing' investment disputes were to some
} 
curtailed the possible exercise of diplomatic protection by the investor's home State (Article 27), thereby providing the host State with "the assurance that it will not be exposed to an international claim by the investor's home State, as long as it abides by the award". 66 These features were described during the negotiations of the ICSID Convention as "significant" and "important" innovations. ${ }^{67}$

\subsubsection{An International Forum Alternative to Domestic Courts}

35. A third reason that is normally said to justify the existence of an international remedy in favor of foreign investors is the need to offer an alternative to domestic courts. ${ }^{68}$ Under usual choice of court rules, domestic courts would normally be the default forum for the settlement of investment disputes. ${ }^{69}$ However, domestic courts are often considered inadequate for the settlement of investment disputes, due in particular to their perceived inefficiency, delays, actual or apparent bias to foreign investors, lack of independence from the host State, which is inevitably the respondent in the dispute, and lack of expertise to apply international law. ${ }^{70}$

36. Upon review of the travaux of the ICSID Convention, the purpose of establishing an international mechanism to provide an alternative to domestic courts appears to have played a relatively less important role compared to other goals (for instance the mentioned de-politicization of disputes). Nevertheless, the relationship between the envisaged dispute resolution machinery and domestic courts was raised on a number of occasions. Certain government delegates, especially from Latin American States, opposed the very idea of allowing a foreign investor direct access to an international forum. ${ }^{71}$ At a meeting in Santiago, for instance, the Argentine and Brazilian delegates observed that the draft Convention would unacceptably confer to an international organization "powers belonging to national institutions" and grant foreign investors "a legally privileged position, in violation of the principle of full equality before the law". ${ }^{72}$ In a similar vein, the expert-delegate from Jordan noted that "the

extent political window-dressing that helped make the idea of arbitration more palatable to capital importers" (St John 2018, p. 120).

${ }^{66}$ Schreuer et al. (2009), p. 416.

${ }^{67}$ ICSID (1968), pp. 164, 242, 403.

${ }^{68}$ See, e.g., Schreuer (2010), p. 71 ("One of the main purposes of investment arbitration is to avoid the use of domestic courts").

${ }^{69}$ Schreuer et al. (2009), p. 5.

${ }^{70}$ See, e.g., Schreuer (2010), pp. 71-72; Bjorklund (2007), pp. 253-256; Schill (2009), pp. 152-153; Schill (2010), p. 33.

${ }^{71}$ See Parra (2012), pp. 54-55. After the conclusion of the ICSID Convention, a number of States remained uncomfortable with the idea of granting direct procedural rights to foreign investors. No Latin American State, for instance, became a party to the ICSID Convention in the 1960s or 1970s. See Newcombe and Paradell (2009), p. 50. Most Latin American States ratified the ICSID Convention in the 1990s, after they had started liberalizing their foreign investment policies. Ibid.

${ }^{72}$ ICSID (1968), pp. 308, 306. 
present Convention seemed to [...] place a foreign investor in a better position than the local investor". ${ }^{73}$ Sporadically, the point was also made that domestic courts were not inadequate to resolve investment disputes. ${ }^{74}$

Broches responded to some of these doubts by explaining that "the proposed new machinery should not be a substitute for local courts and local law". ${ }^{75}$ In his words:

International proceedings became important in the abnormal case, where the normal ways of dealing with disputes proved unsatisfactory, perhaps because of a lack of governmental or judicial stability; perhaps because new legal relationships were being created for which there was as yet no appropriate or competent local forum. Implicit in the convention was the thought that it would be used only in these and other "appropriate cases" ${ }^{76}$

The same idea was then reflected in the Convention's preamble, which reads as follows:

Bearing in mind the possibility that from time to time disputes may arise in connection with such investment between Contracting States and nationals of other Contracting States;

Recognizing that while such disputes would usually be subject to national legal processes, international methods of settlement may be appropriate in certain cases $[\ldots]]^{77}$

Thus, the Convention was not intended to displace dispute resolution before domestic courts; rather, it was conceived to provide an alternative dispute resolution mechanism to be used in appropriate circumstances, where the host State and the investor agreed to it. ${ }^{78}$ However, once the parties consent to arbitration under the Convention, such consent shall exclude "any other remedy", ${ }^{79}$ including domestic courts. ${ }^{80}$ Furthermore, the exhaustion of local remedies is not a condition for resort to arbitration under the Convention unless it is specifically required by the host State. $^{81}$

\footnotetext{
${ }^{73}$ See ICSID (1968), p. 549. See also St John (2018), p. 165.

${ }^{74}$ See, e.g., ICSID (1968), p. 473 (noting that the Australian delegate pointed out that "in practice the remedies provided in Australia by the local courts had to date proved satisfactory to foreign investors").

${ }^{75}$ ICSID (1968), p. 58.

${ }^{76}$ ICSID (1968), p. 58.

${ }^{77}$ ICSID Convention, preamble. See also Report of the Executive Directors on the Convention on the Settlement of Investment Disputes Between States and Nationals of Other States, Section III, 18 March 1965, paras. 10-11.

${ }^{78}$ See Schreuer et al. (2009), p. 6.

${ }^{79}$ See ICSID Convention, Article 26, first sentence (providing that "Consent of the parties to arbitration under this Convention shall, unless otherwise stated, be deemed consent to such arbitration to the exclusion of any other remedy").

${ }^{80}$ See Schreuer et al. (2009), pp. 351-352.

${ }^{81}$ See Article 26 of the ICSID Convention, second sentence (providing that "[a] Contracting State may require the exhaustion of local administrative or judicial remedies as a condition of its consent to arbitration under this Convention”). See also Schreuer et al. (2009), p. 352.
} 


\subsection{Outlook: Does Investment Law Still Need an International Dispute Resolution System?}

40. With the UNCITRAL WGIII reform process underway, questions on the continued desirability of international mechanisms for the resolution of investment disputes are likely to resurface. These questions are expected to be raised in respect of any method in which individuals are allowed to bring international claims against States in their own name, be it investment arbitration, improved through targeted reforms or supplemented with an AM, or a MIC, all of which grant or would grant individuals standing before an international forum.

41. As States debate different reform proposals, they should in particular consider what function international tribunals are to serve and what alternatives foreign investors will have in the absence of an international mechanism. The answers to these questions may vary depending on the emphasis that each State places on its various roles as capital exporter, capital importer, protector of its nationals investing abroad, and potential respondent against claims brought by foreign investors. ${ }^{82}$ The answer for each State may also depend on the particular treaty partner it faces in a specific IIA negotiation, as issues may be viewed differently depending on whether or not the negotiating States share common legal traditions and comparable cultural histories, ${ }^{83}$ and/or place mutual trust in each other's institutions and in particular the judiciary.

42. The question of the function of international tribunals in the area of investment law is linked to whether IIAs and their dispute resolution provisions result in an increase in foreign investment. If one were to conclude that no such positive effect can be observed, it could be argued that the costs for States of keeping in place such a system exceed the benefits. In addition, absent a sound economic rationale, the "double procedural track" for foreign and domestic investors would be more difficult to justify as the modern eye generally disfavors discriminations and the two categories of investors may not always be seen to be in sufficiently different situations to warrant different treatment.

43. In light of the current uncertainty in the research on these matters and the perhaps insurmountable methodological and measurement challenges associated with it, some scholars underscore that it is unrealistic to expect that IIAs and/or dispute settlement provisions granting investors direct rights can alone result in increased FDI in the States that sign those treaties. ${ }^{84}$ It is rather more likely that several factors influence an investor's decision to commit resources in a foreign country (including

\footnotetext{
${ }^{82}$ See Pearsall (2018), pp. 249-254.

${ }^{83}$ For instance, when agreeing to its FTA with Australia, which does not provide for investor-State dispute settlement, the United States justified this choice based on the "unique circumstances of this Agreement - including, for example, the longstanding economic ties between the United States and Australia, their shared legal traditions, and the confidence of their investors in operating in each other's markets [...]". See Dodge (2006), pp. 24-25.

${ }^{84}$ Dolzer and Schreuer (2008), p. 8.
} 
the prospects for profits, tax regime, and general investment climate). However, to the extent that investors take into account the stability of the legal framework, the presence of IIAs and especially the availability of treaty-based mechanisms that stand outside the judicial system of the host State are likely to play a role in their decision to invest.

Seen from this perspective, the presence of an international mechanism for dispute resolution may serve as an important "confidence and credibility-inspiring signal" 85 to foreign investors and would enable host States to be credible when making commitments vis-à-vis foreign investors. ${ }^{86}$ To the extent that foreign investors view international dispute settlement mechanisms as part of a stable legal framework, it cannot be excluded that the absence of such a mechanism may result in decisions not to invest. This was acknowledged, for instance, by the Australian government in its policy statement announcing its intention to do away with investor-State arbitration in the following terms: "If Australian businesses are concerned about sovereign risk in Australian trading partner countries, they will need to make their own assessments about whether they want to commit to investing in those countries". ${ }^{87}$ In a similar vein, it is also possible that companies may restructure their investments in countries where international dispute settlement mechanism remain available in their treaties, which may entail the removal of those investors from the regulatory and taxation regimes of their "real" home States. ${ }^{88}$

When assessing the stability of the legal framework before investing in a country, investors may value the presence of IIAs and of an international dispute settlement method not only for the direct remedy it affords them against the host State, but also for the likely influence which the existence of such substantive and procedural guarantees may exercise on the State's decision-making processes when dealing with foreign investments. Although there is no comprehensive empirical data showing this correlation so far and there is debate amongst scholars as to whether investment treaty law can have a transformative impact on governmental conduct and domestic legal and bureaucratic culture, ${ }^{89}$ it is likely that authorities at least in States with a robust governance do assess the risks of international litigation and responsibility when designing measures that may affect foreign investments. This does not necessarily mean that State initiatives in the area will be frozen in a

\footnotetext{
${ }^{85}$ See Damon Vis-Dunbar and Henrique Suzy Nikiema, Do Bilateral Investment Treaties Lead to more Foreign Investment? Investment Treaty News, 30 April 2009, available at https://www.iisd. org/itn/2009/04/30/do-bilateral-investment-treaties-lead-to-more-foreign-investment/.

${ }^{86}$ See Schill (2010), pp. 29-50.

${ }^{87}$ See Australian Government (Department of Foreign Affairs and Trade), Gillard Government Trade Policy Statement: Trading our way to more jobs and prosperity (April 2011), p. 14.

${ }^{88}$ Trackman (2012), p. 982.

${ }^{89}$ See Joachim Pohl (2018), Societal benefits and costs of International Investment Agreements: A critical review of aspects and available empirical evidence, OECD Working Papers on International Investment, No. 2018/1; Sattorova (2018), Schultz and Dupont (2015), pp. 1147-1168; Jansen Calamita (2015), pp. 103-128; Schill (2015), pp. 81-102; Guthrie (2013), pp. 1152-1200.
} 
so-called regulatory chill, but rather that they would be shaped in such a manner as to conform to the State's international obligations. If this is so, it is likely that the availability of an international remedy may end up preventing the occurrence of situations giving rise to disputes.

46. In its recent Opinion $1 / 17$ on the compatibility of the investor-State dispute settlement mechanisms included in the CETA with EU law, the CJEU also viewed access to international tribunals as a tool aimed at "giv[ing] complete confidence" to investors of one Contracting Party "that they will be treated, with respect to their investments in the territory of the other Party, on an equal footing with the enterprises and natural persons of that other Party, and that their investments in the territory of that other Party will be secure". 90 The Court was notably unconvinced by the argument that CETA would create inequality between foreign (in that case, Canadian) and domestic (in that case, EU) investors, reasoning that the two situations are not comparable because domestic investors do not make "international" investments. ${ }^{91}$ Far from considering access to an international remedy as an unfair advantage for foreign investors, the Court appeared to view the grant of preferential procedural rights as a means of leveling the playing field between foreign and domestic investors. ${ }^{92}$ Importantly, the Court also held that "the independence of the envisaged tribunals from the host State and the access to those tribunals for foreign investors are inextricably linked to the objective of free and fair trade" encapsulated in both the EU treaties and the CETA. ${ }^{93}$

47. In assessing whether it is appropriate to maintain in place or create new international tribunals for the adjudication of investment disputes, States are also likely to consider what the alternatives would be.

48. First, as skeptics of the existing system have noted, ${ }^{94}$ even in the absence of treaty-based mechanisms it would of course be open to investors to seek to negotiate that their preferred dispute resolution clauses (for instance arbitration) be incorporated in their contracts. However, it is possible that only investors with strong bargaining power vis-à-vis the host State will succeed in obtaining their preferred

\footnotetext{
${ }^{90}$ Opinion 1/17 EU Canada Comprehensive Economic and Trade Agreement [2019] ECLI:EU: C:2019:341, para. 199.

${ }^{91}$ Opinion 1/17 EU Canada Comprehensive Economic and Trade Agreement [2019] ECLI:EU: C:2019:341, paras. 180-181.

${ }^{92}$ Opinion 1/17 EU Canada Comprehensive Economic and Trade Agreement [2019] ECLI:EU: C:2019:341, para. 199 ("it must be observed that the purpose of inserting in the CETA provisions concerning non-discriminatory treatment and protection of investments, and the creation of tribunals that stand outside the judicial systems of the Parties to ensure compliance with those provisions, is to give complete confidence to the enterprises and natural persons of a Party that they will be treated, with respect to their investments in the territory of the other Party, on an equal footing with the enterprises and natural persons of that other Party, and that their investments in the territory of that other Party will be secure", emphasis added).

${ }^{93}$ Opinion 1/17 EU Canada Comprehensive Economic and Trade Agreement [2019] ECLI:EU: C:2019:341, para. 200.

${ }^{94}$ See the statement by U.S. Trade Representative Robert Lighthizer at hearing before the U.S. Congress Ways and Means committee, 21 March 2018, supra Chap. 2, footnote 13.
} 
options, whereas small and medium size investors will not. This would create inequalities between different categories of foreign investors. ${ }^{95}$

A second option would be to resort to the traditional inter-State mechanisms that were available in the pre-investment treaty era, based on diplomatic protection. ${ }^{96}$ However, concerns have been expressed by a number of scholars over the re-politicization of disputes which would ensue as a result of a whole-sale shift to inter-State mechanisms. ${ }^{97}$ It has been argued that "[a]s these cases are not actually located at the inter-state level, they should not be framed as disputes between states". ${ }^{98}$ In addition, investors would face the known drawbacks linked to diplomatic protection which is "sporadic, arbitrary in its incidence and prone to politicisation, as there is no control over the process or any form of remedy for the individual whose claim is espoused". 99 Moreover, "[d]iplomatic relations can only tolerate a limited number of intergovernmental disputes" and many disputes concerning in particular "small and medium-sized enterprises (SMEs) and non-governmental organizations (NGOs), will never be selected for a politicized state-to-state dispute". ${ }^{100}$ In other words, it is likely that only powerful economic actors, with leverage over their governments, would be able to obtain intervention from their home State, ${ }^{101}$ which would create further instances of inequalities.

Put another way, the grant of an international forum to foreign investors (in the form of arbitration or standing adjudicatory bodies, such as a MIC) by way of treaty levels the playing field between foreign investors that qualify under that treaty, irrespective of their individual leverage vis-à-vis the host State (when seeking to

\footnotetext{
${ }^{95}$ For an analysis of the different categories of investors who have used investor-State arbitration, see Susan Franck (2019), pp. 76-82. See in particular pp. 76-77 at which Franck notes that "11.4\% of cases involved claims brought solely by individuals" and "that corporate investors, potentially larger with more resources than individuals, dominated [investment treaty arbitration]. Yet cases involving individuals were a notable subcomponent". See also OECD, Government Perspectives on Investor-State Dispute Settlement: A Progress Report, 14 December 2012, p. 7, available at https:// www.oecd.org/daf/inv/investment-policy/ISDSprogressreport.pdf, which reports that "[f]ar from supporting the view that smaller claimants are excluded from ISDS, the survey shows that $22 \%$ of the claimants in both ICSID and UNCITRAL cases are either individuals or very small corporations with limited foreign operations (only one or two foreign projects)".

${ }^{96}$ See the statement by U.S. Trade Representative Robert Lighthizer at hearing before the U.S. Congress Ways and Means committee, 21 March 2018, supra Chap. 2, footnote 13.

${ }^{97}$ Freya Baetens (2015), Transatlantic Investment Treaty Protection - A Response to Poulsen, Bonnitcha and Yackee, Paper No. 4 in the CEPS-CTR project "TTIP in the Balance" and CEPS Special Report No. 103 / March 2015, p. 9; Bronckers (2015), pp. 660 and 674.

${ }^{98}$ Freya Baetens (2015), Transatlantic Investment Treaty Protection - A Response to Poulsen, Bonnitcha and Yackee, Paper No. 4 in the CEPS-CTR project "TTIP in the Balance" and CEPS Special Report No. 103 / March 2015, p. 9.

${ }^{99}$ Freya Baetens (2015), Transatlantic Investment Treaty Protection - A Response to Poulsen, Bonnitcha and Yackee, Paper No. 4 in the CEPS-CTR project "TTIP in the Balance" and CEPS Special Report No. 103 / March 2015, p. 9.

${ }^{100}$ Bronckers (2015), p. 659.

${ }^{101}$ See also Trackman (2012), p. 982 (arguing that "many foreign investors lack access to their home states due to the limited scale of their foreign investments and their lack of sophistication").
} 
negotiate an international dispute settlement option in a contract) or their home State (when seeking to obtain diplomatic espousal).

51. Third, serious concerns have also been expressed about the complete removal of access to international mechanisms for foreign investors such that foreign investors would only have access to domestic remedies.

52. In this respect, States should carefully weigh the costs and benefits of entrusting disputes regarding cross-border investments solely to domestic courts. A thorough comparison between international remedies and domestic remedies should be carried out based on a number of possible parameters, such as costs, duration, efficiency, and independence/neutrality. ${ }^{102}$ Of particular concern to States assessing whether to forfeit entirely recourse to international remedies for investors in favor of domestic courts is likely to be judicial independence, risk of government interference, and neutrality. Annual studies produced by various institutions show that courts in a large number of States still face significant problems with respect to judicial independence or at least with the perceptions of independence. ${ }^{103}$

53. Furthermore, it has been highlighted that problems of delays and even due process are seen in both developed and developing countries, as is shown by the human rights breaches that are not infrequently found by the various regional human rights courts, for instance the European Court of Human Rights (ECtHR) under Article 6 of the European Convention on Human Rights (ECHR).

54. Finally, if investment disputes are entrusted solely to domestic courts, it should not be underestimated that in many cases disputes will only be capable of being settled by reference to domestic law, not international law, as in a number of countries IIAs cannot be invoked directly before the local courts. ${ }^{104}$ This means

\footnotetext{
${ }^{102}$ There is no comprehensive empirical evidence comparing costs and duration of international dispute settlement mechanisms (in particular investment arbitration) with litigation in domestic courts. See Bonnitcha et al. (2017), pp. 88-89.

${ }^{103}$ See in particular Klaus Schwab (2018), World Economic Forum. The Global Competitiveness Report, available at http://www3.weforum.org/docs/GCR2018/05FullReport/ TheGlobalCompetitivenessReport2018.pdf. See also, the "Justice Scoreboard" prepared annually by the European Commission to monitor the independence, quality and efficiency of justice systems in the EU Member States, which notes that "[t]he perceived independence of the judiciary is a growth-enhancing factor, as a perceived lack of independence can deter investments" (see European Commission (2019), The 2019 EU Justice Scoreboard, May 2019, COM(2019) 198/2, p. 44), and also refers to a study indicating "a positive correlation between perceived judicial independence and Foreign Direct Investment flows in Central and Eastern Europe", p. 4. It is interesting to observe that, even in a highly developed area such as the European Union, whose Member States generally rank high in global charts concerning judicial independence and good governance generally, (see Klaus Schwab (2018), World Economic Forum The Global Competitiveness Report referred to above), the Commission identifies certain shortcomings and lack of perceived independence in the justice systems of some of the Member States (see European Commission, The 2019 EU Justice Scoreboard (EU 2019), pp. 44-46) and notes at p. 55 that "[a]mong the reasons for the perceived lack of independence of courts and judges, the interference or pressure from government and politicians was the most stated reason, followed by the pressure from economic or other specific interests".

${ }^{104}$ See infra at 3.2.2.1.
} 
that in the absence of an international dispute resolution mechanism before which the substantive standards contained in IIAs may be invoked, in those countries in which IIAs cannot be directly invoked these standards would become a dead letter.

Two final points should be made. First, despite the fact that investment arbitrations have often made the headlines in the media, it should not be overlooked that the vast majority of disputes between foreign investors and host States are resolved in national courts, rather than before international tribunals. ${ }^{105}$ Thus, continuing to make international dispute settlement available is unlikely to change this fact. Second, acknowledging that there may be continuing reasons to maintain or establish international remedies for investors (whether in the form of arbitral tribunals, with or without an AM, or a standing MIC) in no way prevents States from recalibrating the interplay between domestic courts and international mechanisms as they deem appropriate based on their policy preferences and perceived needs. This is examined in the next sections, which review the interactions between domestic courts and the international mechanisms in the existing system (infra at Chap. 3), and explore the possible interplay in future dispute resolution frameworks (infra at Chap. 4).

\section{References}

Allee T, Peinhardt C (2011) Contingent credibility: the impact of investment treaty violations on foreign direct investment. Int Organ 65(3):401-432

Berger A, Busse M, Nunnenkamp P, Roy M (2011) More stringent BITs, less ambiguous effects on FDI? Not a BIT! Econ Lett 112:270-272

Berger A, Busse M, Nunnenkamp P, Roy M (2013) Do trade and investment agreements lead to more FDI? Accounting for key provisions inside the black box. Int Econ Econ Policy 10 (2):248-275

Bjorklund AK (2007) Private rights and public international law: why competition among international economic tribunals is not working. Hast Law J 59:241-308

Bonnitcha J, Skovgaard Poulsen LN, Waibel M (2017) The political economy of the investment treaty regime. Oxford University Press

Broches A (1995) Settlement of investment disputes, address to the world conference on world peace through law. In: Broches A (ed) Selected essays: World Bank, ICSID, and other subjects of public and private international law. Martinus Nijhoff, p 163

Bronckers M (2015) Is investor-state dispute settlement (ISDS) superior to litigation before domestic courts? An EU view on bilateral trade agreements. J Int Econ Law 18:655-677

Chaisse J, Bellak C (2011) Do bilateral investment treaties promote foreign direct investment? Preliminary reflections on a new methodology. Transnl Corp Rev 3(4):3-10

Chaisse J, Bellak C (2015) Navigating the expanding universe of international treaties on foreign investment creation and use of a critical index. J Int Econ Law 18:79-115

Dodge WS (2006) Investor-state dispute settlement between developed countries: reflections on the Australia-United States Free Trade Agreement. Vanderbilt J Transnl Law 39(1):1-37

Dolzer R, Schreuer C (2008) Principles of international investment law, 1st edn. Oxford University Press, p 8

\footnotetext{
${ }^{105}$ See Bonnitcha et al. (2017), pp. 82, 84-85.
} 
Franck S (2019) Arbitration costs, myths and realities in investment treaty arbitration. Oxford University Press, pp 76-82

Frenkel M, Walter B (2019) Do bilateral investment treaties attract foreign direct investment? The role of international dispute settlement provisions. World Econ 42(5):1316-1342

Galbraith J (2019) Contemporary practice of the United States relating to international law, NAFTA is renegotiated and signed by the United States. Am J Int Law 113(1):150-159

Gertz G, Jandhyala S, Poulsen LNS (2018) Legalization, diplomacy, and development: do investment treaties de-politicize investment disputes? World Dev 107:238-252

Guthrie BK (2013) Beyond investment protection: an examination of the potential influence of investment treaties on domestic rule of law. N Y Univ J Int Law Polit 45:1152-1200

ICSID (1968) History of the ICSID Convention: documents concerning the origin and formulation of the Convention on the Settlement of Investment Disputes between States and Nationals of Other States, vol II-1. ICSID, p 242, 303

Jansen Calamita $N$ (2015) The rule of law, investment treaties and economic growth: mapping normative and empirical questions. In: Jowell J, Christopher Thomas J, van Zyl Smit J (eds) Rule of law symposium 2014: the importance of rule of law in promoting development. Singapore Academy of Law and Bingham Centre for the Rule of Law, pp 103-128

Johnson L, Volkov O (2013) Investor-state contracts, host-state "commitments" and the myth of stability in international law. Am Rev Int Arbitr 24(3):361-415

Kerner A (2009) Why should I believe you? The costs and consequences of bilateral investment treaties. Int Stud Q 53(1):73-102

Kleinheisterkamp J (2012) Investment protection and EU law: the intra- and extra-EU dimension of the Energy Charter Treaty. J Int Econ Law 15(1):85-109

Kriebaum U (2018) Evaluating social benefits and costs of investment treaties: depoliticization of investment disputes. ICSID Rev Foreign Invest Law J 33(1):14-28

Miles K (2013) The origins of international investment law: empire, environment and the safeguarding of capital. Cambridge University Press, pp 86-87

Neumayer E, Spess L (2005) Do bilateral investment treaties increase foreign direct investment to developing countries? World Dev 33(10):1567-1585

Newcombe A, Paradell L (2009) Law and practice of investment treaties: standards of treatment. Wolters Kluwer, pp 44-46

Noel Maurer C (2013) The Empire trap. The rise and fall of U.S. intervention to protect American Property Overseas, 1893-2013. Princeton University Press

Orrego Vicuña F (2004) International dispute settlement in an evolving global society: constitutionalization, accessibility, privatization (Hersch Lauterpacht Memorial Lectures 2001 Lauterpacht Research Centre for International Law University of Cambridge). Cambridge University Press, pp 31-32

Paparinskis M (2010) The limits of depoliticisation in contemporary investor-state arbitration. In: Crawford J, Nouwen S (eds) Select proceedings of the European Society of International Law, vol 3. Hart, pp 271-282

Parra AR (2012) The history of ICSID. Oxford University Press, pp 54-55

Parvanov PP, Kantor M (2012) Comparing U.S. law and recent U.S. investment agreements: much more similar than you might expect. In: Sauvant KP (ed) Yearbook on international investment law \& policy 2010-2011. Oxford University Press, pp 741-836

Pauwelyn J (2014) At the edge of chaos? Foreign investment law as a complex adaptive system, how it emerged and how it can be reformed. ICSID Rev Foreign Invest Law J 29(2):372-418

Pearsall P (2018) The role of the state and the ISDS trinity. AJIL Unbound 112:249-254

Price DM (2000) Some observations on chapter eleven of NAFTA. Hast Int Comp Law Rev 23:421-429

Price DM (2011) Chapter 11 - Private Party vs. Government, investor-state dispute settlement: Frankenstein or safety valve? Canada-US Law J 26:107-114

Sattorova M (2018) The impact of investment treaty law on host states: enabling good governance? Hart

Schill SW (2009) The multilateralization of international investment law. Cambridge University Press, pp 152-153 
Schill SW (2010) Private enforcement of international investment law: why we need investor standing in BIT dispute settlement. In: Waibel M, Kaushal A, (Liz) Chung K-H, Balchin C (eds) The Backlash against investment arbitration. Wolters Kluwer, pp 29-50

Schill SW (2015) International investment law and the rule of law. In: Jowell J, Christopher Thomas J, van Zyl Smit J (eds) Rule of law symposium 2014: the importance of rule of law in promoting development. Singapore Academy of Law and Bingham Centre for the Rule of Law, pp 81-102

Schreuer CH (2010) Interaction of international tribunals and domestic courts in investment law. In: Contemporary issues in international arbitration and mediation: The Fordham Papers, vol 4, pp 71-94

Schreuer CH, Malintoppi L, Reinisch A, Sinclair A (2009) The ICSID Convention-a commentary, 2nd edn. Cambridge University Press, $\mathrm{p} 4$

Schultz T, Dupont C (2015) Investment arbitration: promoting the rule of law or over-empowering investors? A quantitative empirical study. Eur J Int Law 25(4):1147-1168

Shihata IFI (1986) Towards a greater de-politicisation of investment disputes: the roles of ICSID and MIGA. ICSID Rev Foreign Invest Law J 1(1):1-32

St John T (2018) The rise of investor-state arbitration: politics, law, and unintended consequences. Oxford University Press, pp 154-161

Swenson DL (2005) Why do developing countries sign bilateral investment treaties? UC Davis J Int Law Policy 12:131-155

Tobin J, Rose-Ackerman S (2006) Bilateral investment treaties: do they stimulate foreign direct investment? Yale University Law School E-Publications, pp 1-42

Tortian A (2012) The impact of bilateral investment treaties and financial development on foreign direct investment: evidence from Eurasia. Paper Submission for the Armenian Economic Association Conference, Haigazian University, Yerevan, Armenia (13-14 October 2012), pp $21-22$

Trackman L (2012) Choosing domestic courts over investor-state arbitration: Australia's repudiation of the Status Quo. UNSW Law J 35(3):979-1012

UNCTAD (2014) IIA Issue Note - Working Draft, the impact of IIA on FDI: an overview of empirical studies 1998-2014. UNCTAD, p 5

Van Harten G (2010) Five justifications for investment treaties: a critical discussion. Trade Law Dev 2(1):19-58

Vandevelde K (1998) Investment liberalization and economic development: the role of bilateral investment treaties. Columbia J Transnl Law 36:501-527

Vandevelde KJ (1988) Reassessing the Hickenlooper Amendment. Va J Int Law 29(1):115-168

Vandevelde KJ (2009) U.S. International investment agreements. Oxford University Press, pp 29-30

Yackee JW (2008) Bilateral investment treaties, credible commitment, and the rule of (international) law: do BITs promote foreign direct investment? Law Soc Rev 42:805-832

Open Access This chapter is licensed under the terms of the Creative Commons Attribution 4.0 International License (http://creativecommons.org/licenses/by/4.0/), which permits use, sharing, adaptation, distribution and reproduction in any medium or format, as long as you give appropriate credit to the original author(s) and the source, provide a link to the Creative Commons licence and indicate if changes were made.

The images or other third party material in this chapter are included in the chapter's Creative Commons licence, unless indicated otherwise in a credit line to the material. If material is not included in the chapter's Creative Commons licence and your intended use is not permitted by statutory regulation or exceeds the permitted use, you will need to obtain permission directly from the copyright holder.

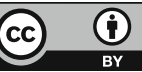

